\title{
Community conservation in transition
}

\author{
Wolfram Dressler* \\ Melbourne University, Melbourne, Australia
}

\begin{abstract}
This paper tries to explore more about the transition of community conservation in some areas around the world. There were some changes from the community conservation, which occurred from changing times and modernization itself. With the push of neoliberalism that is getting stronger, community conservation is changing. The empowerment of the indigenous people to save nature has some challenges to improve society's awareness about nature. Of course, this momentum needs a process to get expected results.
\end{abstract}

Keywords: community, conservation, transition

\section{INTRODUCTION}

When it emerged in the 1970s as a modern policy and practice - from the FAO to grassroots NGOs - community-based conservation rested on a seemingly intuitive assumption: because local people already use, rely on and manage natural resources, they are in the best position to conserve them (with external assistance as needed) (see FAO 1978). Over subsequent decades, the realization grew that top-down, centralized management can drive access restrictions at the expense of local knowledge and well-being (Agrawal \& Gibson 1999). Policymakers and scientists found that centrally managed government systems had failed to curb deforestation and resource over-exploitation, and so moved to devolve initiatives to support a range of community-oriented conservation initiatives. In time, emphasis shifted to work with rather than 'on' local and indigenous peoples in the Global South. Much of this shift was based in figuring out how to best harness local and indigenous peoples' management abilities and knowledge to make forest conservation less disruptive to local livelihoods and more empowering to local people (Berkes 1989; Marcus 2001; Brosius et al. 2005). Various grassroots approaches to community conservation soon emerged to challenge previously centralized, state-controlled regimes of industrial forestry and governance regimes (Berkes 1989; Marcus 2001).

\section{RESULT AND DISCUSSION}

Such devolved approaches included everything from integrated conservation and development projects to community-based forest management, among others. In most cases, the programs and approaches varied in degree rather than kind: sharing a similar ethos of 'small is [not only] beautiful' (Schumacher 1973) but also collaborative, empowering, efficient and effective (Chambers 1983; Western \& Wright 1994). Intuitively appealing, the community-based approach has maintained currency across disciplines and practices for decades (Dressler et al. 2010). In forestry, particularly, it has remained an enduring paradigm. While interpretations have varied, community forestry, or community conservation more generally, can be seen as an incremental social process of assisting

\footnotetext{
*Corresponding author: wolfram.dressler@unimelb.edu.au
} 
impoverished communities to set priorities and make decisions for developing forest resources in order to reduce livelihood vulnerability and improve forest conservation locally (Berkes 1989, 2004; Western \& Wright 1994).

Several decades have now passed involving critical analysis of community conservation, with a range of social scientists drawing on case studies from the around the work to reconsider the relative potential and pitfall of such interventions across scale. In the last decade, a burgeoning literature has begun to examine how the institutional 'design' and 'packaging' of community conservation has been 'scaled up' as part of international governance regimes that are part of global climate change mitigation and biodiversity conservation efforts (Smith \& Dressler 2019). Such investigations reveal how such local-global convergence may complicate community-based interventions. In the current, globalized era of neoliberal dominance, community conservation finds itself at the nexus of transnational currents bringing profound socio-ecological change (e.g., boom crop production), regional market integration (e.g., ASEAN (Association of Southeast Asian Nations)), burgeoning extractive industries (e.g., mining), and market-based environmental governance (e.g., REDD + (Reduced Emissions from Deforestation and Degradation)). Indeed, while the 1980-1990s saw greater emphasis on community conservation as a tool for achieving social well-being, poverty reduction and conservation with some broadly successful cases (e.g., Ikalahan Foundation (Balooni et al. 2008), the 2000s saw the idea of community conservation being scaled up as part of global policy arrangements and institutional frameworks. As Berkes (2007) noted, in an increasingly globalized world institutions have linked local processes (in particular, traditional knowledge, practices, and resources) to higher levels of social and political organization, spanning global scales.

\section{CONCLUSION}

In recent decades, community conservation ideals and procedures have been increasingly been incorporated into major international political-administrative frameworks aligned with neoliberal logic: with private sector support, community conservation would operate under market incentives to produce more 'value-added' commodities and engage in carbon offsetting and payments for ecosystem services schemes (Dressler et al. 2010). In the process, scholars have suggested that the discourse and practice of community conservation has become so entangled in market-oriented bureaucracies that organizational forms and relationships increasingly define procedures for local implementation, rather than the reverse (Lewis and Mosse, 2006). In being scaled up, some suggest that community conservation tends to be rolled out with predefined policy prescriptions that identify problems and solutions from dominant agency norms and beliefs (Dressler et al., 2010). As Li (2002) notes, these processes render otherwise complex situations into packaged, technical solutions that mismatch with the reality of local settings. What, then, does the future of community conservation hold?

\section{REFERENCES}

Agrawal, A. and Gibson, C. C. (1999) 'Enchantment and disenchantment: The role of community in natural resource conservation', World Development. doi: 10.1016/S0305-750X(98)00161-2.

Balooni, K., Pulhin, J. M. and Inoue, M. (2008) 'The effectiveness of decentralisation reforms in the Philippines's forestry sector', Geoforum. doi: 10.1016/j.geoforum.2008.07.003.

Berkes, F. (1989) 'Common property resources: ecology and community-based sustainable development', Common property resources: ecology and community-based sustainable development. doi: 10.1016/09218009(91)90040-1.

Berkes, F. (2004) 'Rethinking community-based conservation', Conservation Biology. doi: 10.1111/j.15231739.2004.00077.x.

Brosius, J. P., Tsing, A. L. and Zerner, C. (2005) Communities and Conservation Histories and Politics of Community-Based Natural Resource Management. AltaMira Press. 
Chambers, R. (1983) Rural development: putting the last first. Harlow: Prentice Hall.

Dressler, W. et al. (2010) 'From hope to crisis and back again? A critical history of the global CBNRM narrative', Environmental Conservation. doi: 10.1017/S0376892910000044.

Food and Agriculture Organization of the United Nations Forestry Department (1978) Forestry for Local Community Development. Rome: Food \& Agriculture Org.

Lewis, D. and Mosse, D. (2006) 'Encountering order and disjuncture: Contemporary anthropological perspectives on the organization of development', Oxford Development Studies. doi: 10.1080/13600810500495907.

Li, T. M. (2002) 'Engaging simplifications: Community-based resource management, market processes and state agendas in upland Southeast Asia', World Development. doi: 10.1016/S0305-750X(01)00103-6.

Marcus, R. R. (2001) 'Seeing the forest for the trees: Integrated conservation and development projects and local perceptions of conservations in Madagascar', Human Ecology. doi: 10.1023/A:1013189720278.

Schumacher, E. F. (1973) Small Is Beautiful: A Study of Economics As If People Mattered. Blond \& Briggs.

Smith, W. and Dressler, W. (2019) 'Governing vulnerability: The biopolitics of conservation and climate in upland Southeast Asia', Political Geography. doi: 10.1016/j.polgeo.2019.04.004.

Western, D. and Wright, R. M. (1994) Natural connections: perspectives in community-based conservation. Island Press. 